\title{
Globalization, democratization, and the Arab Uprising: The international factor in MENA's failed democratization
}

\author{
Raymond Hinnebusch* \\ University of St. Andrews \\ Published in Democratization, March 2015
}

\begin{abstract}
What explains the almost negative impact of international factors on post-Uprising democratization prospects? This article compares the utility of rival "diffusionist" and neo-Gramscian political economy frames to explain this. Three international factors deter democratization. The failure of Western democracy promotion is rooted in the contradiction between the dominance of global finance capital and the norm of democratic equality; in the periphery, neo-liberalism is most compatible with hybrid regimes and, at best, "low intensity democracy." In MENA, neo-liberalism generated a crony capitalism incompatible with democratization; while this also sparked the uprisings, these have failed to address class inequalities. Moreover at the normative level, MENA hosts the most credible counter-hegemonic ideologies; the brief peaking of democratic ideology in the region during the early uprisings soon declined amidst regional discourse wars. Non-democrats-coercive regime remnants and radical charismatic movements--were empowered by the competitive interference of rival powers in Uprising states. The collapse of many Uprising states amidst a struggle for power over the region left an environment uncongenial to democratization.
\end{abstract}

Keywords: Globalization, democracy promotion, finance capital, crony capitalism, hegemony, counter-hegemony, Arab Uprising

Do international level variables advance or retard democratization in MENA? The Arab Uprising, when local agents finally embraced democratic discourse, seemed a sign that the globalization of democracy had finally overcome "Middle East exceptionalism." Despite this, the impact of the international level on the Uprising has been almost uniformly negative. It has helped destabilize the region, but has done little to enable democratic transition, much less consolidation.

The conventional democratization approach to the international variable might be called the diffusionist model by which democracy is exported from the Western core via a combination of emulation, leverage and linkage, with regional lags increasingly overcome by globalization-driven homogenization. Although utilizing evidence by those working in this tradition, this article adopts an alternative neo-Gramscian framework, ${ }^{1}$ that sees the export of a "democratic" capitalist order to MENA as highly contingent. In this view, the stability of a global or regional order depends on congruence between the system of production and ideological hegemony promoted by global institutions and a hegemonic state. While MENA has been incorporated into circuits of Western finance capital and brought under US military hegemony, the hegemony of Western norms remains highly contested, the regions' alternative state formation pathways highly resilient, and on-going power struggles over the region productive of norm fragmentation little congenial to democratization.

The article first examines the literature on the international export of democratic capitalism in the age of globalization; then looks at its impact on MENA prior to the

\footnotetext{
*E-mail: rh10@st-andrews.ac.uk
} 
Uprising; and finally examines the impact of post-2011 international and regional power struggles in shaping the outcome of the Uprisings.

\section{Democratization within the frame of globalization}

Democratization, in the neo-Gramscian view, must be understood within the framework of economic globalization, a process constituted by the internationalization of production and the dominance of Western finance capital and a Westcentric transnational corporate class. The globalization of capitalism requires the sustained agency of the global hegemon of the age, now the US, empowered by the dominance of its finance capital ${ }^{2}$ and working through international financial institutions, to promote "disciplinary neo-liberalism" 3 manifest in international contractual arrangements such as the World Trade Organization. Especially in the world periphery, the hegemon plays a key role in forcing open markets to Western penetration, using economic crises and debt relief to enforce neo-liberal measures such as Anglo-American legal practices, tariff removal, privatization and structural adjustment. ${ }^{4}$ The hegemon seeks thereby to transform states into transmission belts of global neo-liberalism. ${ }^{5}$ With the demise of Soviet countervailing power, this US project acquired enhanced leverage; e.g. war could again be used to force open the most recalcitrant and lucrative periphery markets, notably oil-rich Iraq. ${ }^{6}$

At the levels of institutions and ideology, sociological institutionalists (world polity theory) see a parallel process in which a world culture of capitalist democracy is diffused outward from core to periphery. ${ }^{7}$ Buzan and Little noted that the expansion of European international society through imperialism, globalized a formally Westphalian states system and stimulated an internalization of Western norms of sovereignty and nationalism, that made denial of the independence of periphery too costly. ${ }^{8}$ In a geopolitical dynamic recognizable to realists whereby the international system shapes the states, via socialization and emulation, a convergence in governance took place: since the capitalist national state is best able to mobilize power in international competition, all states emulated this model through defensive modernization. ${ }^{9}$ In the era of de-colonization, these twin dynamics propelled a real diffusion of power to the periphery; however, Clark showed that, to compensate, the core engineered the globalization of neo-liberal practices, creating an international society of only semisovereign states in the periphery. ${ }^{10}$

What is the link between neo-liberal globalization and democratization? While globalization created a capitalist global political economy that ostensibly facilitated democratization, Western states also actively manipulated it to export democracy. As theorized notably by Levitsky and Way ${ }^{11}$, globalization gave Western states leverage over weaker less developed countries (LDCs) via sanctions, diplomatic pressures, conditionality and intervention. However, their pressures were most effective where paralleled by linkage:socio-economic penetration and interdependencies resulting from economic integration. Linkage, via diasporas, media penetration and the internet could tilt the internal power balance toward democratization, by creating and empowering constituencies pressing for it: Western-financed transnational non-governmental organization (NGO) networks built up civil society, and emergent regional elites were socialized through educational exchanges. Solingen ${ }^{12}$ saw responsiveness to the Western democracy promotion as advanced by the rise inside non-democratic regimes of business-dominated "internationalist coalitions" at the expense of statist-nationalist ones, a function of the move from bi-polarity, when authoritarian national security states had been fostered by super-power patrons, to a US-centric neo-liberal world 
empowering Western-linked bankers, finance ministers, and trading bourgeoisies. Finnemore and Sikkink ${ }^{13}$ showed that states were socialized into standards of "civilized" international society notably by international organizations and NGOs that linked external and internal liberal norm entrepreneurs, such as democratization activists, to spread norms domestically. Huntington ${ }^{14}$ identified a "snowballing" effect in which the de-legitimation of authoritarian governance made democracy appear to be the only legitimate form of rule and Rosenau ${ }^{15}$ stressed how transnational linkages encouraged anti-authoritarian movements to spill across borders, as was famously the case in the Arab spring. The dominant ideology was that economic success required democratization, which alone had the legitimacy, predictability and informational advantages needed to encourage investors and innovation--while authoritarian regimes fostered economically counterproductive rent seeking.

In parallel, as reflected in "World Society"16 approaches, there was a normative shift from an international society based on sovereign equal states to one wherein sovereignty was made conditional on "good governance" and states' fulfilment of their "responsibility to protect," with human rights violations justifying intervention-all as judged and implemented by the great powers, above all the US hegemon. The export of the non-violent resistance paradigm, popularized by Gene Sharp and theorized by Stephan and Chenoweth ${ }^{17}$ publicized the techniques by which activists could use nonviolent protest to provoke the collapse of authoritarian regimes; this is said to have played some role in inspiring the techniques of the Arab Uprising. Less often observed was, as Ayoob and Lustick ${ }^{18}$ suggested, how human rights and democratization campaigns aimed to deprive late developing states, for better or worse, of the tools of violence earlier used in the consolidation core states, hence perpetuating state weakness in the periphery that sustained core dominance over it.

These one-way diffusionist models capture important tendencies, but greatly oversimplify reality, in neglecting three important counter-realities. Firstly, there is arguably a contradiction within the norm package exported by globalization that works against smooth norm diffusion. Thus, paradoxically, even as globalization appears to be an engine in the horizontal spread of democratization, it paradoxically also dilutes it: in locking states into trade pacts that remove much economic policy, particularly economic rights, from political contestation, democracy is hollowed out as the economic policies of all political parties converge on the neo-liberal consensus, big money and big corporate media manipulate elections and electorates are de-politicised or set against each other over race and immigration issues. The function of states changes from the provision of social needs to disciplining their societies as needed to attract global finance capital via a "race to the bottom;" the state becomes more accountable to transnational capital and less to its citizenry. In the periphery, the consequences have been particularly damaging. While in the core, Sorensen observed, 19 democratic consolidation was normally accompanied by periods of growing affluence and equality, globalization produces inequality on a world scale ${ }^{20}$ and, as Boix ${ }^{21}$ found, this high inequality undermined democratization in the periphery. What the West exported to the periphery was democratic procedure without the substance of political equalization, or, in Robinson's words, "low intensity democracy." 22 For Huntington, unless economic development consolidated new democracies, a reverse authoritarian wave was likely; ${ }^{23}$ and, as Petras and Veltmeyer ${ }^{24}$ argued, globalization often generated some hybrid form of "electoral" or neo-authoritarianism." In short, while the global hegemony of Westcentric international financial capital has reconstituted massive economic inequality on a global scale, it simultaneously the core exports the formal procedures of 
democracy (elections, independent judiciaries) emptying it of its substance-political equality.

Second, the diffusionist narrative obscures the fact that democratization is a power struggle, and hence depends on the power of the global hegemon, backed by a Westcentric "collective hegemon' that promotes it. The legitimacy of the US hegemon is, however, strongest in the core and weakest in the periphery and the less legitimacy it enjoys, the more it must rely on more costly hard power to enforce democratic capitalism. As Hegemonic Stability Theory acknowledges, such "liberal imperialism" makes the hegemon very vulnerable to imperial overreach which damages its economy and encourages rising alternative powers to contest its hegemony; ${ }^{25}$ while the US was, in the 1990-2002 period, largely unconstrained by such countervailing power, beginning with the highly contested Iraq war, other powers began to soft-balance against Washington and after the failure of the Iraq intervention and the global financial crisis, the US retreated to "offshore balancing" in the Middle East. After Iraq, authoritarian regimes were able to undermine the legitimacy of democracy-promotion by depicting it as American interventionism. Also, as Levitsy and Way ${ }^{26}$ acknowledged, Western leverage was diluted when applied to larger states that the West could not afford to destabilize (e.g. Saudi Arabia) or ones with alternative global patrons (e.g., Iran); indeed, Brazil, Russia, India and China (the BRICS) had coalesced to soft balance against the US. They aimed to promote a global power balance supportive of a renewed plurality of global norms and a return to the primacy of state sovereignty in international society. Democracy promotion had provoked a backlash by the second half of the 2000, with a growing number of governments expelling Western NGOs and prohibiting local groups from taking foreign funds. ${ }^{27}$ In these new conditions, when democratic revolts took place, rather than provoking a global consensus against authoritarian regimes, they were more likely to become a matter of international power contestation, with pro-democracy intervention countered by non-democratic or neighbouring states fearful of the demonstration effect or the threat to the regional power balance. ${ }^{28}$ Contesting sides inside states undergoing revolt sought to draw in outside powers on their side, further destabilizing rather than democratizing them.

Thirdly, intervening between the global core and the periphery states is, as Buzan and Wæver ${ }^{29}$ argue, the level of regions, which have their own structuresnorms, power balances, patterns of amity-enmity--which are at least partly constituted 'bottom upward,' hence reflective of "thicker" regionally specific variations in interhuman society that are buffers against global influence. March and Olsen showed that path dependencies from historically specific regional experiences prevent quick adaptation to what are promoted as superior global models, with a typical outcome hybridity; thus, for Sharabi Western penetration of MENA's patriarchal societies created a reinforced neo-patriarchal order. ${ }^{30}$ In regions outside the Western core, liberalism, far from a triumphant, has to compete with or accommodate nationalism and religion. In MENA it encounters a "grass roots counter-hegemony" 31 in the form of Islam, which has superseded socialism as the ideology of protest for the deprived. Islamists created patriarchal versions of civil society activism that could provide the social basis of semidemocratic regimes in which popular sovereignty would be checked by the "sovereignty of God" (the ulama interpreting the sharia). The socializing effect of "linkage" would be also be much diluted where substantial cultural differences overlapped with political economy factors: thus, the reinforcement of tribal culture by oil rent-funded clientelism in the Gulf short-circuits the linkage posited by modernization and democratization theory between increased education and increased participatory demands. Where, as in 
the Middle East, no (legitimized) hegemonic order has been established, rival norms will be promoted by rival agents in their power struggles, with the likely outcome hybridity. ${ }^{32}$ Political change may still mean movement away from authoritarianism but toward various hybrids ranging from low intensity consociational democracy as in Lebanon to competitive authoritarianism such as Iran's theo-democratic power sharing between ulama and elected politicians.

\section{MENA under neo-liberal globalization \\ The political economy of MENA: between authoritarianism and democratization}

The main longer-term structural factor shaping regime formation in MENA is its distinctive political economy--to which correspond state institutions and agents with ideologies, initially shaped in a first wave of globalization in which the Western world expanded into MENA. The Marxist theory of uneven and combined development tells us that late developers' defensive modernization leads to hybrid institutions mixing capitalist and pre-capitalist features. ${ }^{33}$ In the MENA case where the modern states system was literally imposed from without by Western imperialism in what David Fromkin ${ }^{34}$ called a "peace to end all peace," and in violation of the dominant identities of the region's peoples, artificial states had to compete with powerful pre-existing sub- and supra-state forces for the loyalties of their populations, and hence suffered built-in legitimacy deficits. In these circumstances, formally liberal, actually oligarchic, institutions that Western imperialism had put in place quickly collapsed and Arab state builders gravitated toward neo-patrimonial practices that combined time-honoured indigenous state-building formulas (Ibn Khaldun's ${ }^{35}$ assabiya or elite solidarity built on primordial ties) with imported modern bureaucratic machinery and surveillance technology. In parallel, at the level of political economy, the penetration of the capitalist mode of production into MENA, articulating with pre-capitalist modes, produced, according to Ayubi, ${ }^{36}$ a fluid social structure lacking a hegemonic class wherein a dominant state filled the vacuum. Populist authoritarian (PA) regimes originating in the military coups of petit bourgeois officers, often bound by a particular communal solidarity (assabiya), seized the command posts of the army and bureaucracy. These state elites balanced between the fragments of communally and territorially fragmented classes while forging populist alliances against the old oligarchy joining national capital and workers/peasants, incorporated thru corporatist syndicates, rather than pluralist civil society. In the PA Arab republics that emerged in the 1950-60s, "Bonapartist" states (prefigured in Marx's analysis of Napoleon III) launched "passive" revolutions "from above." While demolishing the class power of the old oligarchy through nationalizations and land reform, they generated their own state bourgeoisies via statist import substitution industrialization; and balanced in international politics between communism and capitalism, getting aid from both sides. This formula was empowered, perhaps beyond its shelf life, by the exceptional availability of hydrocarbon and geopolitical rent in the region after the mid-1970s, which enabled the lubrication of clientele networks, the clientelization of "pre-democratic" regime-supportive tribes and communal minorities, and also a populist "social contract" with the masses. Rents gave the state considerable autonomy of society and allowed it to co-opt segments of the business class, a context hostile to democratization which requires a class balance between the state and bourgeoisie. At the ideological level both governing elites and masses were illiberal, depriving the small secular liberal middle class of leverage while authoritarianism was successfully legitimized in the name of nationalist resistance to imperialism. ${ }^{37}$ 
The exhaustion of state capitalism and economic and fiscal crisis into which PA regimes fell from the 1980s onward made them extremely vulnerable to Western international financial institutions (IFIs), such as the World Bank and International Monetary Fund (IMF), which used debt relief to force them into "structural adjustment." In parallel, within regimes, as Higgott and Dodge ${ }^{38}$ argued, neo-liberalism started winning as power shifted from public sector managers to finance and economy ministries staffed by Western educated technocrats with direct connections to international financial institutions and reflecting neo-liberal ideological hegemony at the global level. But as Guazzoni and Poppi ${ }^{39}$ showed, economic liberalization did not lead to diminishing state control or a more independent civil society or bourgeoisie; rather, Presidential families exploited IFI's demands for privatization of the public sector to seize its choicest elements as their private property and to generate supportive crony capitalists who were heavily invested in relations with the West. IFIs commended Tunisia and Egypt, where the cronies of Gamal Mubarak and the Ben Ali family took advantage of their pressures for privatization to turn public sector assets into private monopolies, as models of good economic governance. ${ }^{40}$

Globalization in MENA was not, therefore, associated with democratization. Rather, authoritarian power persisted but was now used, not to attack inequalities, as in the populist period, but to reconstruct and protect the new inequalities unleashed by the region's opening (infitah) to the global economy. Under this new 'post-populist' authoritarianism, regimes restructured their social bases. Thus, privatization provided regime elites with new patronage resources to foster and co-opt a supportive crony capitalist class. ${ }^{41}$ This new class base was, contrary to globalization discourse, incompatible with democratization: crony capitalists would be threatened by democratic transparency but also even productive capitalists wanted rule of law for themselves but not rights for workers. Rather than a hegemonic bourgeoisie capturing the state and instituting limited democracy for itself, much of the bourgeoisie became dependent on the state for contracts, business opportunities, rent and the disciplining of labour, allowing rulers to play off rival business cliques. While capitalism is said to empower bourgeoisies and working classes who combine to force democratization, in MENA economic liberalization and privatization obstructed such a democratic coalition and was used to build anti-democratic coalitions-"networks of privilege" 42 --reempowering authoritarianism.

At the same time, reviving capitalism meant investors had to be favoured over the mass public through reduction of labour rights and wages while IMF structural adjustments contracted populist welfare, producing 'food riots' across the region (while leaving intact military purchases from Western arms dealers); enforcing this required the old popular constituencies be demobilised; hence democratization, which could empower them to resist neo-liberalism, could not be promoted. Moreover, rollbacks of the populist social contract on which regimes had initially built their legitimacy and abdication of their developmental and welfare roles to the private sector and religious charity networks made regimes vulnerable to the rise of Islamic opposition, that powerfully attracted the marginalised strata victimised by neo-liberal policies and were well poised to win elections, should they be liberalized. Rulers, on the other hand, could hardly expect to win a democratic election when they were forcing austerity unequally on the majority and violating people's sense of moral economy, excluding, not including them, as the populist regimes had initially done. Contrary to mainstream globalization discourse, neo-liberalism, reinforcing rather than diluting regional neo-patrimonialism, posed a major obstacle to democratization. 
As such, globalization was paralleled by a move toward hybrid regimes via 'lopsided political liberalization,' in which greater access was accorded the beneficiaries of post-populism: the interest groups of the bourgeoisie were given greater corporatist and parliamentary access to power and more rule of law. Elections were manipulated to empower bourgeois parties supportive of neo-liberalism and marginalise populist ones, with safety valve opposition parties for the middle class tolerated only within strict limits; and corporatist arrangements, which in the populist era had allowed mass organizations access to decision-makers, becoming instruments for disciplining and demobilizing mass strata. ${ }^{43}$ It was against this 'post-populist authoritarianism' that the Arab intifada of 2011 mobilised.

Authoritarian persistence was reinforced by the role of the region in the world system. Democracy develops when governments need their citizenry to pay taxes or to fight in wars but in the Middle East many states depended on the outside--on rents (oil revenues or foreign aid) in lieu of taxes and on foreign bases and security treaties instead of citizen armies. Democracy achieves hegemony when associated with nationalism, as in the French and American revolutions; but MENA regimes forfeited nationalist legitimacy through their alignment with the US, which was, with Israel, the most unpopular state in Middle East public opinion. ${ }^{44}$ Thus, where democratisation even partly proceeded in MENA, it unleashed anti-Western or anti-Israeli sentiments that challenged regimes' Western-aligned foreign policies and which Islamic movements exploited, prompting a halt or reversal of these experiments. The case of Jordan shows most dramatically how a regime's responsiveness to Western demands-for peace with an Israel unwilling to concede Palestinian rights--was necessarily paralleled by a contraction of domestic democratisation. Conversely, the 'war on terror' cemented new political alliances between the US, Britain and France and MENA authoritarian regimes against the common threat from radical Islam. On the other hand, authoritarian upgrading took advantage of a certain authoritarian solidarity (e.g. Russian or Chinese support) and in some cases also the use of anti-Western nationalism to discredit democracy discourses. Both threats from the West and from Islamists were used to securitize politics.

\section{Western democracy promotion in MENA}

During the first decade of Western democracy promotion, MENA was largely exempted, with security and stability of allied regimes given priority over democratization. In the 1990 Gulf war the US punished Jordan and Yemen for following public opinion and rewarded Mubarak for ignoring it. Washington's post-war presence in the Gulf depended on absolute monarchies and it even expressed alarm that Yemen's democratization would infect Saudi Arabia. The war on terror aligned Washington with authoritarian regimes against Islamic opinion: the US backed the Algerian military's overturning of an Islamist electoral victory and its violent suppression of Islamists while US NGOs praised Algeria's 1997 elections that excluded Islamists. The biggest US aid recipients, Egypt and Jordan, did not hold free elections. ${ }^{45}$ Ray Takeyh attributes this to the fear Islamists would benefit from democratization and from the need for partner regimes willing to deal with Israel, help in the "war on terror" and deliver oil. ${ }^{46}$ In parallel, Amaney Jamal sees the Arab bourgeoisie embracing authoritarianism and alliance with the US as a bulwark against Islamists and popular power. ${ }^{47}$

Much more proactive in MENA was the European Union (EU) which, through the Mediterranean Partnership, acted collectively vis-a-vis the fragmented MENA states in a systematic drive to pry open regional markets for European businesses. The 
partnership, in ending protection for industries in the southern Mediterranean while only marginally expanding access to European markets for MENA agricultural products, reversed the advantages given LDCs under Cold War preferential trading arrangements. ${ }^{48}$ Hyde-Price ${ }^{49}$ argues that the EU promoted market opening while neglecting democratization and human rights. EU defenders claimed the economic development that the partnership supposedly promoted would lead to democratization over the long run and that EU officials encouraged incremental political progress through dialogue and economic incentives rather than antagonizing regimes with predictably ineffective political demands. This strategy would, however only be effective if neo-liberalism did lead to economic development; however, as Joffe ${ }^{50}$ observed, no economy has ever developed under the economic openness the EMP mandated; rather authoritarian regimes were needed to implement free trade agreements that pauperized MENA populations. ${ }^{51}$

The Bush administration announced an end to tolerance of authoritarianism after $9 / 11$ on the grounds that it was the root cause of terrorism, hence that Western security required democratization. Washington launched new democracy promotion campaigns without consulting pro-US regimes, as if, declared Egypt's Mubarak, MENA states had no sovereignty. ${ }^{52}$ Coming in parallel with the war on Iraq and a sharp US tilt toward Israel, the initiative triggered a string negative reaction by Arab commentators and journalists, congruent with public opinion, among whom it was seen as serving Israel's interests by debilitating Iraq and a means of pressuring regimes to be more cooperative on Palestine and Iraq's occupation. The US calls for human rights while ignoring Palestinian rights had no credibility; also the Gulf oil regimes were always exempted. Many intellectuals and civil society groups were pulled between their nationalist rejection of Western interference and fear that democracy would not come without some outside pressure; in Egypt Western pressures opened limited space that allowed the strongly anti-Mubarak Kefiya movement to emerge. The technical approach of the West, notably the stress on elections and on fostering civil society was widely criticized; and, despite the emphasis on elections, when Hamas won a free election in Palestine, the West refused to recognize or deal with it and the fear of Islamist victories eased the pressure on regimes for elections. ${ }^{53}$ Lynch $^{54}$ argued that US support for Israel and antagonism to Iran so alienated regional publics that US regional influence depended on marginalization of publics by authoritarian regimes; it was no surprise that Bush soon abandoned democracy promotion.

The Western export of democracy to the region was widely seen to fail, indeed, to deter democratization in spite of the considerable leverage and a reasonable level of linkage. It was seen as an instrument of US hegemony; as Teti ${ }^{55}$ argued, it put the West in a privileged position to judge governance in MENA states and the West's insistence on secular liberal versions of democracy combined with neo-liberal economics, while marginalizing Islamic versions of democracy and discouraging redistributive measures, had limited appeal in MENA. The democratization promoted by the West was of the "thin" variety compatible with neo-liberal globalization. While as an ideology democracy made gains in the region, it faced too much competition from counter ideologies to be hegemonic, and the balance of social forces produced by the articulation of global neoliberalism with MENA crony capitalism was most compatible with hybrid regimes and at best with "low intensity" democracy (Tunisia, Lebanon). 


\section{The Uprising: democratization between structure and agency \\ Global level Precipitants}

Global level pressures played a key role in destabilizing the fragile post-populist authoritarian regimes in MENA. While the globalization of neo-liberalism reduced their ability to satisfy the welfare of mass publics, the parallel promotion of democratization and the spread of Internet technology encouraged anti-regime political mobilization by middle class youth "overproduced" by population growth and educational expansion. Activists trained by US government funded democracy promotion campaigns and West European NGOs played a certain role in spreading the Uprising. ${ }^{6}$ The "responsibility to protect," doctrine conveyed the misapprehension to dissident activists that the West would intervene should repression exceed certain limits. The US invasion of Iraq had also empowered sectarian discourses that spread outward across the region, reinforced by Saudi-Iranian rivalry; the nominally consociational democracy left behind by the US in Iraq, with its built-in Shia majority, was actually a failed state that would provide fertile ground for the anti-democratic ISIS movement.

The Uprisings provided a new context for competitive interference by global powers that blocked any straightforward export of democracy. The US was ambivalent about the Uprisings, which constituted a threat to key allies, notably Egypt, where Mubarak was deposed and Saudi Arabia, which was threatened by insurgents in Yemen and protests in Bahrain. But the West also saw opportunities to reincorporate Libya and Syria into the Westcentric democratic capitalist order and to roll back the growing regional influence of Russia and China, which had growing stakes in arms deals, energy partnerships, and trade with authoritarian regimes. What was remarkable was that while Western democracy promotion was, for once, in sync with social movements in the region, the outcome was no straightforward expansion of the democratic-capitalist world. The West's abuse of the United Nations resolution authorizing humanitarian intervention in Libya to effect regime change activated Russia and China's strong interest in defending the norm of sovereignty against Western expansion in MENA at the expense of the multi-polar world order they sought, ${ }^{57}$ which was also congruent with the interests of anti-Western MENA regimes and movements. Also, with regional turmoil not lending itself to management by military means and chastened by its adventure in Iraq and lingering austerity from the world financial crisis, Washington retreated to its traditional "off shore balancing" in MENA, content to contain and exploit regional cleavages, notably the Sunni-Shia conflict most manifest in Syria and Iraq where anti-Western Shia and Sunni movements were fighting each other.

\section{The Regional Trans-state level: the construction and de-construction of democratic ideological hegemony}

The first regional manifestation of the Uprising was the unleashing of a trans-state ideological struggle. The Uprisings were accompanied by a powerful mobilization of pro-democracy sentiment in the region, parallel to the weakening and collapse of several authoritarian states. What was remarkable was that while Bush's forced democratization, unleashing civil war in Iraq and Lebanon, had seemingly discrediting the notion in the 2000s, the demands of the 2011 youth movements and rebellions were chiefly for democracy and freedom in their own states, rather than the traditional PanArab, anti-imperialist, concerns that had dominated the 2000-2010 "New Arab Cold War." 58 Even more remarkable was that significant segments of regional opinion put aside their traditional suspicion of Western interference to call for intervention under 
the banner of responsibility to protect and against the heavy repression deployed by regimes in Libya and Syria in particular.

In parallel to democratization discourses, the uprisings also empowered Islamic identity. The main initial beneficiary was the Muslim Brotherhood whose electoral prowess, backed by Turkey and Qatari money and media, propelled its simultaneous rise toward the levers of power in several states, seemingly on the brink of realizing its moderate Islamic version of democracy; had it prevailed, the third wave might finally have penetrated the Arab world. With variants from the Ikhwan tradition ruling in the pivotal capitals of Ankara and Cairo, and kindred movements empowered or in government in Tunisia, Morocco, Yemen, Palestinian Gaza, and Libya, a new Islamic version of democracy that eschewed the anti-democratic and sectarian exclusionary Wahhabi version, seemed on the cusp of achieving hegemony. Other Islamists, such as the formerly anti-democratic Salafis, joined the democratic political game while alQaida's was marginalized by the peaceful overthrows of dictators, especially when its new leader Ayman Al-Zawahiri, denounced the principle of majority rule, defying the yearning of Muslim populations for democracy.

However, in parallel, Saudi Arabia fostered conservative Salafis in Egypt and Syria against both secular democratic youth and the Brotherhood and also used Sunni Salafism against Iran as part of their geo-political struggle; combined with the parallel use of non-Sunni sectarian solidarity by the Syrian and Bahraini regimes against their uprisings, sectarian conflicts soon spread insecurity and defensive sectarian solidarity in Lebanon, Syria, Bahrain, Yemen and Iraq, which would make democratization impossible. In parallel, the ailing fortunes of Al-Qaida and its various avatars was reversed, thriving on sectarian polarization and new opportunities in the failing states of Libya, Yemen, Syria and Iraq. Moreover, by the third year of the uprisings, state national security establishments were recovering some of their lost capacity in a fightback, notably in Egypt and Syria, against both democratization and Islamization. A watershed was the overthrow of President Morsi in Egypt by an alliance between secularist liberals and the army and deep state. It was encouraged by a tacit alliance of Israel, which covered the military's flank in Washington, with Saudi Arabia, which provided copious financial support and brought Egypt's Salafis into the new military dominated ruling coalition. This marked a triumph of counter-revolutionary and antidemocratic forces regionally. On the one hand, liberals began to abandon a democracy that would empower Islamists; on the other hand the trend toward democratization of Islamic movements was reversed by the demonstration in Egypt that Islamic movements that won elections would not be allowed to rule. The absolute monarchies, Saudi and UAE especially, which had encouraged the military, along with their polarizing sectarian Sunni discourse, were empowered and the democratic Islamic threat to them diluted. Far from the democratic mobilization leading to the hegemony of democratic norms, it had unleashed normative fragmentation.

\section{Competitive Interference amidst the regional struggle for power}

At the regional level the Uprising intensified the pre-existing regional power struggle between the Iran-led "resistance axis" and the Sunni-dominated pro-Western axis led by Saudi Arabia. Three regional powers, Saudi Arabia, Iran and Turkey, with enough material and soft power and sufficient invulnerability to the Uprising to try to use it to bid for regional hegemony in the name of quite different models of governance, with only Turkey ostensibly promoting democratization. This precipitated the inter-state power balancing which realism expects will block bids for hegemony: as a result, the 
region was fragmented as no power managed to use the Uprising to shape a new regional order under its hegemony.

Saudi Arabia (and the Gulf Cooperation Council): A new "Holy Alliance":

The Uprising initially appeared a major threat to the monarchies. The loss of Mubarak's Egypt, state failure in Yemen, where they and Iran backed opposing sides in the Houthi rebellion in the north, and al-Qaida was also finding space to operate; and the possiblycontagious Shia uprising in Bahrain were perceived as opportunities for Iran. But the monarchies dampened the potential spread of revolt to their own populations via a combination of repression, most obvious in Bahrain; political concession, most obvious in Morocco, and economic blandishments to citizens, most obvious in Saudi Arabia where $\$ 5,000 /$ citizen worth of jobs and benefits were promised. ${ }^{59}$ The Gulf Cooperation Council (GCC) was ungraded into a counter-revolutionary "Holy Alliance," de facto incorporating Morocco and Jordan, with the rich GCC states transferring billions of dollars to the poorer monarchies to enable them to similarly appease discontent, crowned by anti-revolutionary intervention in Bahrain. Certainly, their financial liquidity glut allowed them to fund trans-state Islamists against secularists and buy influence on a massive scale in Uprising states, particularly Egypt. 60 The GCC also went on the offensive, taking advantage of its media dominance and its bloc vote in the Arab League to legitimize the Western intervention against old foes Qaddafi and Asad. AlJazeera was overtly political, exaggerating and widely disseminating regime violence in Syria while ignoring repression in Bahrain and instances of violence by the Syrian opposition. However, splits between Riyadh and Doha over their sponsorship of rival (Muslim Brotherhood, Salafi) Islamists put the GCC at cross-purposes: the two backed rival Islamists in Egypt and in also in Syria where Gulf-funded Islamists fought both the regime and each other, helping to produce a failed state. In inflaming Islamist militancy and anti-Shia sentiment, the GCC helped empower al-Qaida avatars such as ISIS. Saudi Arabia's backing for the military in Egypt against Turkish and Qatari promotion of the Muslim Brotherhood helped precipitate an internal conflict that ended in a hybrid regime in Cairo.

Turkey: failed liberal hegemon:

The rise of the Adalet ve Kalkinma Partisi (AKP) government to power in 2000 initiated a transformation in Turkey's Middle East policy. Its policy of 'zero problems' with its neighbours, aimed to ameliorate the interminable regional conflicts left behind by the fall of the Ottoman empire by exporting the liberal practices of the zone of peace. An active diplomacy sought to resolve disputes, project Turkey as a model of an economically successful Islamic democracy, and appeal to an Islamic civilization shared by Turks and Arabs. Economic integration aimed to construct new cross-border "liberal" interdependencies that would also permit the export of Turkish business in need of regional markets. 61

The Arab Uprising initially upset Turkey's strategy, which had prioritized economic integration with its Arab neighbourhood regardless of their authoritarian governance. Turkey initially opposed North Atlantic Treaty Organization intervention in Libya where it had close business ties with the regime. But the then prime minister, now president, Recep Tayyip Erdoğan switched his discourse to the championing of democratization as the region-wide rise of kindred business/Islamist coalitions similar to the AKP in the apparently-emerging Sunni democracies in Tunisia and Egypt provided new openings to Turkish soft power. The congruity of its political system--a 
democracy that incorporates Islamic forces--with regional popular aspirations, was demonstrated by the hero's welcome given Erdoğan in his 2011 tour of these countries. ${ }^{62}$

It was in Syria that Turkish policy ran aground. Syria had been the showcase of its zero-problems strategy where trans-state issues of conflict, such as the disputed Turkish annexation of Iskanderun, Euphrates water, and Kurdish separatism, had been resolved amidst the opening of borders to free passage and free trade agreements, which were meant to be extended into the Levant and Gulf areas. However, when the Syrian Uprising started and Asad dismissed Turkey's calls to contain it through political reforms and instead continued repressing protestors, the AKP now professed to see repressive dictatorships as the most serious threat to its ambition for a pacific neighbourhood and democracy as the solution. It sacrificed its ties with Asad's regime, helped organize the Syrian opposition and gave it safe haven to operate an insurgency from Turkish territory. If, as Turkey expected, the minority Alawi regime had quickly collapsed and been replaced by the Muslim Brotherhood opposition, the AKP could have expected to enjoy special influence in Damascus. However, Erdoğan had grossly underestimated the tenacity of the Asad regime, bolstered by its allies in the resistance axis, Iran and Hizbollah. Turkey appeared impotent even to manage the spillover of the crisis-refugee flows, Kurdish empowerment-on its borders. Its attempt to export democracy to its neighbour had the same outcome as the earlier US attempt in Iraq: collapse into a failed state. In calling on the West to intervene in Syria, Ankara jettisoned its earlier notion of a Middle East zone of peace as an alternative to misguided American interventions. In deploying Sunni Islamic identity against the secular/Alawi regime in Damascus, Ankara contributed to the sectarianization that was destabilizing the region. Turkey was soon on bad terms with other Middle East states, too. Over Syria it sacrificed its good relations with Iran. Iraq's Shia-led government objected to Ankara's manipulated of its ties to Iraqi Sunnis and Kurds against Baghdad. When Turkey objected to the overthrow of President Morsi and Egyptian moves to isolate Hamas in Gaza, ties with Cairo turned sour.

The new struggle for Syria: the perils of exporting the non-violent resistance paradigm:

In Syria, the Uprising began as a mobilization of protestors demanding democratization against a repressive authoritarian regime, arguably a test of the non-violent resistance model which anticipates the use of violence against mass non-violent protest will precipitate either defections in the security forces or external sanctions and intervention. Indeed, the possibility of external military intervention shaped both opposition and regime strategies. Western funded Syrian expatriates, young cosmopolitans that were instrumental in initiating and internationalizing the Uprising, understood that they could not succeed without external intervention to restrain the regime's repressive options. External activists told those on the ground, pointing to the Libya no-fly zone, that "the international community won't sit and watch you be killed." They claimed that another Hama was not possible because "Everything is being filmed on YouTube, and there's a lot of international attention on the Middle East." 63 This encouraged Syrian activists to risk their lives and to eschew the compromise with the regime needed for a pacted transition. The Libyan intervention gave decisive momentum to the uprising. ${ }^{64}$

The regime, for its part, having survived several decades of Western isolation, had always seen itself as besieged by foreign enemies; the role played by external exiles and internet activists abroad in provoking or escalating the Uprising was congruent 
with its perceptions of conspiracy and tarnished the indigenous opposition with the suspicion of treasonous dealings with foreign enemies, justifying the resort to repressive violence. The regime tried to calibrate its violence within limits that would not trigger an international bandwagon toward intervention, although over time this bar was steadily raised. Later yet, it felt the need to quickly smash resistance so as not to lose control of territory that could be used to stage intervention as had happened in Libya, thus precipitating a transition from the "security solution" to the "military solution." This did not precipitate Western intervention for, in contrast to Libya, the consensus behind humanitarian intervention had been destroyed by Western-led regime change in Libya.

Repression did precipitate some defections from the Syrian military, not enough to precipitate regime collapse but enough that the regime lost control of wide swathes of the northeast of the country to armed insurgents. The struggle for Syria became a regional and international proxy war; regionally, with Turkish, Saudi and Qatari support for the opposition being offset by Iranian, Hizbollah and Iraqi support for the regime; and internationally, through American and European support for the Uprising offset by Russian and Chinese support for the regime. Iran proved a tenacious power balancer: on the defensive, Tehran sought to create a protective land belt from via Iraq (where postUS occupation, the move of the Maliki regime against Sunni rivals made it more dependent on Iran) to Syria, and Hizbollah. These external involvements, each blocking the other, contributed to the stalemating of the Syrian conflict, especially as the insurgents began to fight among themselves, pitting more moderate Syrian rebels against transnational al-Qaida avatars, Jabhat al-Nursa and the Islamic State of Iraq and Syria (ISIS). With rising levels of jihadist involvement, the West became more concerned with the "international war on terror" than with the "Responsibility to Protect."

\section{Egypt and Tunisia: Neo-Liberalism Redux:}

Democratic uprisings do not guarantee democratic consolidation: the two regional states with the least fragmented societies and most developed institutions, hence the best prospects for democratization, faced a political economy stacked against consolidation. The revolutions in Egypt and Tunisia were a reaction against the acute social inequalities resulting from neo-liberalism, but the revolutions remained purely political, with no attempts to attack unjust economic inequalities. This was because enduring dependencies on the Western-centred international financial system locked them into neo-liberal practices. Indeed, because the uprisings has actually worsened economic growth, hence prospects for addressing unemployment, by deterring investors and tourism, they were more dependent on Western IFIs. Particularly in Egypt IFIs tried to exploit the post-Uprisings economic crises to making loans conditional on further opening to international finance capital, notably privatizations that would allow Western and Gulf investors to buy up prime parts of Egypt's infrastructure and public services. 65

In this context, the least bad outcome was the "low intensity democracy" that appeared possible in Tunisia where long-term Western cultural penetration may indeed have assist democratic consolidation--ironically, even when the West supports the authoritarian leader, as was the case with Ben Ali. If democracy is consolidated in Tunisia, it will be because moderates were able to reach a pact to marginalize the radicals on both sides, despite the French supporting anti-clericalists and the Gulf supporting Salafists. But even in Tunisia, nostalgia set in for the stability and relative prosperity of the Ben Ali period; all that had changed for the unemployed was increased 
political freedom to express their frustrations. In Egypt, where political competition was diverted from economic injustice to identity issues framed in de-stabilizing zero-sum terms and backed by competitive interference from the US, Saudi Arabia, and Qatar, the result was a hybrid regime: mixing some political pluralism with doses of authoritarian power needed to manage identity conflicts and turn back demands for social justice that could not be accommodated in a global neo-liberal economic order.

\section{Conclusion:}

The diffusionist approach, with its image of both benign and inevitable global diffusion of democratic capitalism (each believed to reinforce the other) from the core provides little explanation for the failure of democratization in post-Uprising MENA, except the notion of time lags, perhaps attributable to cultural exceptionalism, a mechanical view that neglects agency. Neo-Gramscianism offers a far more robust explanation; for it, the exportability of a stable democratic-capitalist world order to the periphery depends on congruence between forces of production and hegemonic norms. However the contradictions within the Western core's version of world order debilitated its exportable power.

The West has certainly left a profound impact on MENA but it has not been benign and has therefore inevitably generated resistance. In a first wave of globalization the West imposed an arbitrary and flawed states system made up of fragile regimes wherein early liberal experiments rapidly failed and more indigenous hybrids of neopatrimonialism and populism became the main state building formulas. The second wave of globalization at the end of the Cold War exposed these regimes to the powerful homogenizing material forces (finance capital, markets), triumphant liberal ideology (via transnational linkages and the new globalized communications technology) and the dominance of a liberal global hegemon, the US, which increasingly penetrated the region. However, rather than these reinforcing each other, the incongruence in the Western project prevented achievement of hegemony over the region.

The core's export of democracy suffered, first of all, from a built-in contradiction between the global inequality generated by neo-liberalism and the democratic norm of equality. The US hegemon cannot bridge this contradiction because it lacks both the hard and soft power to control the region and provokes anti-hegemonic balancing by global and regional powers. The incoherence of global liberalism inevitably generates regional backlashes, with counter-ideologies, nationalist populism and Islamism, retaining remarkable power in MENA, with the latter the only credible counterhegemonic ideology opposing triumphant world liberalism.

Moreover, MENA regimes have proved extremely resilient in the face of globalization, and indeed adept in using global resources-investment, arms, technology-to adapt. In the oil-poor republics, regimes, such as the Tunisian and Egyptian ones, selectively exploited global neo-liberal pressures to reconstitute statist authoritarian regimes in inegalitarian crony capitalist forms quite resistant to democratization. In parallel, the Arab regimes most incorporated into Westcentric global financial networks, the Arab Gulf state were the least democratic, not only internally, but also in their use of finance capital to promote anti-democratic forces.

To be sure, the vulnerabilities of the authoritarian republics were exposed in the Arab uprising, when communications globalization, enabling the export of democratization discourses--pushing for the empowerment of populations even as regional incarnations of neo-liberalism generated grievances among themprecipitated the Arab revolt, profoundly de-stabilizing the region. The Arab uprisings 
were both a symptom of globalization and a backlash against it, a continuation and intensification of struggle between those seeking to make regional states transmission belts of neo-liberalism and those wanting to protect the indigenous moral economy.

In spite of the opportunity presented by the Uprisings to tilt internal power balances, Western and regional intervention in the Arab uprisings states promoted not democratization but intensified de-stabilization. Neither leverage or linkage gave the West the influence to peacefully promote democratization while militarized intervention proved disastrous in Libya, as it had earlier been in Iraq, with the state demolished, empowering militias and trans-state jihadists rather than democrats; even when intervention was expected but not delivered, as in Syria, it encouraged rebellion and with similar results.

Further diluting any democratizing normative impetus was the global norm fragmentation deepened by the Arab Uprising, pitting the West's "liberal imperialist" "humanitarian" interventionism against Russian and Chinese defence of sovereignty in which each checkmated the other rather than cooperating to facilitate a stable regional transition. Similarly, at the regional level, Uprising states became targets of competitive interference by rival powers backing opposing forces and also largely checkmating each other. Even the presence of an aspirant liberal-Islamic hegemon, Turkey, was unable make democracy normatively hegemonic. Rather, external intervention (sanctions, arms supplies) in internal power struggles (Syria, Libya) magnified and prolonged a deepening destabilization of states that was profoundly inhospitable to democratization.

As regional states fractured under the effect of internal revolt, contrary norms were wielded in domestic power struggles between middle class liberal activists, "deep" state establishments and rival versions of Islamism that either rejected or selectively embraced aspects of Western defined democratic norms. Democrats proved inferior to statist authoritarians and Islamist radicals who had either more guns, money or ideological motivation-and much of it came from external sources. Indicative of the negative impact of external-global and regional-interference in the Arab Uprising states was the inverse relation between the likelihood of democratization and the intensity of external competitive interference: where it was most intense, the result was failed states (Libya, Syria); where it was significant, Bonapartist restoration (Egypt); and only where it was most muted did "low intensity democracy" result (Tunisia).

\section{Notes}

1 Cox, "Social Forces, State and world orders"

2 Arrighi and Silver, "Capitalism and world (dis) order."

${ }^{3}$ Gill, Power and Resistance.

${ }^{4}$ Gowan, The Global Gamble; Harvey, The New Imperialism

${ }^{5}$ Cox and Sinclair, Approaches to World Order, p 193

${ }^{6}$ Barkawi and Laffey, "The Imperial Peace," 403; Hartnett and Stengrim, Globalization and Empire.

7 Finnamore, "Norms, Culture and World Politics."

8 Buzan and Little, "The Historical Expansion."

${ }^{9}$ Waltz, The Theory of International Politics; Finnamore, "Norms, Culture and World Politics."

10 Clark, "Another double movement"

11 Levitsky and Way, "International Linkage and Democratization."

12 Solingen, Regional Orders.

13 Finnamore and Sikkink, "International Norm Dynamics."

14 Huntington, "Democracy's Third Wave."

15 Rosecrance, Linkage Politics 
${ }^{16}$ Buzan, From International to World Society

${ }^{17}$ Stephan and Chenoweth, "Why Civil Resistance Works."

${ }^{18}$ Ayoob, The Third World Security Predicament; Lustick, "The Absence of Middle Eastern Great Powers,"

${ }^{19}$ Sorensen, Democracy \& Democratization, 125-6

${ }^{20}$ Hartnett and Stengrem, Globalization and Empire, 140.

${ }^{21}$ Carles Boix, Democracy and Distribution.

22 Robinson, Promoting Polyarchy.

${ }^{23}$ Huntington, "Democracy's Third Wave."

${ }_{24}$ Petras and Veltmeyer, Globalization Unmasked, 70.

${ }^{25}$ Robert Gilpin, War and Change in World Politics, 153-6. 217-19

${ }^{26}$ Levitksy and Way, "International Linkage"

27 Thomas Carothers, "The Backlash Against Democracy Promotion."

${ }^{28}$ Fred Halliday, Revolution, pp. 207-233.

${ }^{29}$ Buzan and Weaver, Regions and Powers, 6-26

${ }^{30}$ Hisham Sharabi, Neo-Patriarchy.

${ }^{31}$ Adamson, "Global Liberalism vs. Political Islam;" Murden, Islam, the Middle East and the New Global Hegemony, ch 4.

32 Bacik, Hybrid Sovereignty

33 Callinicos and Rosenberg, "Uneven and Combined Development."

${ }^{34}$ Fromkin, A Peace To End All Peace.

${ }^{35}$ Salame, "Muqaddimah"

${ }^{36}$ Ayubi, Overstating the Arab State, 26-30

37 Pratt, Democracy and Authoritarianism

38 Dodge and Higgott, Globalization and the Middle East.

${ }^{39}$ Guazzone, and Pioppi, The Arab State

${ }^{40}$ Saif, "Arab Leaders and Western Countries;" Zurayk, "Feeding the Arab Uprisings."

${ }^{41}$ King, The New Authoritarianism

${ }^{42}$ Heydemann, Networks of Privilege.

${ }^{43}$ Hinnebusch, "Authoritarian Persistence;" Glasser, Economic Development and Political Reform

${ }^{44}$ Furia and Lucas, 'Determinants of Arab Public Opinion."

45 Gambill, "Explaining the Arab Democracy;" Lynch, The Arab Uprising, 223-25.

46 Takeyh, "Close but no Democracy."

47 Jamal, Of Empires and Citizens.

48 Hinnebusch, "Europe and the Middle East"

${ }^{49}$ Hyde-Price, A. "Normative power Europe."

${ }^{50}$ Joffe, G. (1994). "Relations between the Middle East and the West," 66-8.

${ }^{51}$ Durac and Cavatorta, "Strengthening Authoritarian Rule thorough Democracy Promotion."

52 Ehteshami, Globalization and Geopolitics; Ottoway and Carothers, "The Greater Middle East Initiative."

53 Delacoura, "US Democracy Promotion"

${ }^{54}$ Marc Lynch, The Arab Uprising, p. 217.

55 Teti, "The Globalization of Democracy"

${ }^{56}$ Nixon. "US Groups"

57 Blank, "Russia's Anxieties"

${ }^{58}$ Tamlali, "The 'Arab Spring."

${ }^{59}$ Shehadeh, "Economic Costs, the Arab Spring and the GCC,"

${ }^{60}$ Heydarian, How Capitalism Failed the Arab World, 128-50.

${ }^{61}$ Hinnebusch and Tur, Turkey-Syria Relations.

${ }^{62}$ Barkey, "Turkey and the Arab Spring."

${ }^{63}$ Seelye, "Syria Unrest."

${ }^{64}$ Lynch, The Arab Uprising, p. 165

65 Hanieh, "International Aid" 


\section{Bibliography}

Adamson, Fiona, "Global Liberalism vs. Political Islam, Competing Ideological Frameworks in International Politics," International Studies Review, no. 4 (2005), 547-69.

Arrighi, Giovanni and Beverly Silver, "Capitalism and world (dis) order" in Michael Cox, Tim Dunne and Ken Booth (eds.),. Empires, Systems and States: Great transformations in International Politics, 257-79. Cambridge: Cambridge University Press, 2001.

Ayoob, Mohammed, The Third World Security Predicament, State Making, Regional Conflict and the International System, Boulder CO: Lynne Rienner Publishers, 1995

Ayubi, Nazih, Overstating the Arab State: Politics and Society in the Middle East, London: I.B Tauris, 1995.

Bacik, Gokhan, Hybrid Sovereignty in the Arab Middle East: the Cases of Kuwait, Jordan and Iraq, NY: Palgrave-Macmillan, 2008

Barkawi, Tarik and Mark Laffey, "The Imperial Peace: Democracy, Force and Globalization," European Journal of International Relations, 1999.

Barkey, H. J., "Turkey and the Arab Spring," 26 April 2011, Available at: http:// carnegieendowment.org/2011/04/26/turkey-and-arab-spring/2s3\#comments

Blank, Stephan, "Russia's Anxieties About The Arab Revolution," E-Notes, Foreign Policy Research Institute, July 2012, www.fpri.org

Boix, Carles, Democracy and Distribution, Cambridge: Cambridge University Press, 2003.

Buzan, Barry, From International to World Society: English School Theory and the Social Structure of Globalization, Cambridge: Cambridge University Press, 2004

Buzan, Barry and Richard Little, "The Historical Expansion of International Society," August 2008. In: Denemark, Robert Allen, (ed.) The International Studies Encyclopedia.

Chichester, UK: Wiley-Blackwell.

Buzan, Barry and Ole Weaver, Regions and Powers: the structure of international security, Cambridge: Cambridge University Press, 2003.

Callinicos, Alex and Justin Rosenberg, "Uneven and Combined Development: the social relational substratum of the international?" Cambridge Review of International Affairs, 21no 1 (2008) 77112

Carothers, Thomas, "The Backlash Against Democracy Promotion," Foreign Affairs, March/April, 2006

Clark, Ian "Another double movement; the great transformation after the Cold war," in Cox et.al, Empires, 237-255, Empires, Systems and States: Great transformations in International Politics, 257-279. Cambridge: Cambridge University Press, 2001

Cox, Richard, "Social Forces, State and World Orders," in Richard Cox with Timothy Sinclair, Approaches to World Order, 85-123. Cambridge: Cambridge University Press, 1996. 
Delacoura, Katerina, "US Democracy Promotion in the Arab Middle East after 11 September 2001: a critique," International Affairs, 81, no. 5, 2005, 963-79

Dodge, Toby and Richard Higgott, eds., Globalization and the Middle East: Islam, economy, society and politics, eds. London: Royal Institute of International Affairs, 2002.

Durac, Vincent, and Francesco Cavatorta, "Strengthening Authoritarian Rule thorough Democracy Promotion: Examining the Paradox of EU and US Security Strategies," British Journal of Middle Eastern Studies, 36, no. 1, 2009.

Ehteshmai, Anoushirivan, Globalization and Geopolitics of the Middle East, Routledge, 2007.

Finnamore, Martha, Norms, Culture and World Politics: Insights from Sociology's institutionalism," International Organization, 50: no. 2 (1996), 325-347

Finnamore, Martha and Kathryn Sikkink, "International Norm Dynamics and Political Change, "International Organization, 52, no. 4, (1998), 887-917.

Fromkin, David, A Peace To End All Peace: Creating the Modern Middle East 1914-1922. New York: Henry Holt \& Company, 1989.

Furia, Peter A. and Russell E. Lucas, 'Determinants of Arab Public Opinion on Foreign Relations', International Studies Quarterly, 50 (2006), 585-605.

Gambill, Gary C. "Explaining the Arab Democracy Deficit, Part II: American Policy, " Middle East Intelligence Bulletin, 5, nos. 8-9 (August-September 2003)

Gill, Stephen, Power and Resistance in the New World Order (Basingstoke and New York: Palgrave/Macmillan, 2003).

Gilpin, Robert, War and Change in World Politics, Cambridge: Cambridge University Press.

Glasser, Bradley Louis, Economic Development and Political Reform: The Impact of External Capital on the Middle East, Cheltenham, UK: Edward Elgar, 2001

Gowan, Peter, The Global Gamble: Washington's Faustian Bid for World Dominance (London: Verso, 1999.

Guazzone, Laura and Daniela Pioppi, The Arab State and neo-liberal Globalization: the restructuring of the state in the Middle East, Reading: Ithaca Press, 2009

Halliday, Fred, Revolution and World Politics, Basingstoke: Macmillan 1999.

Hanieh, Adam "International Aid and Egypt's Orderly Transition," Jadaliyya, May 29, http://www.jadaliyya.com/pages/index/1711/egypts-'orderly-transition'-international-aid;

Harvey, David, The New Imperialism, London: Oxford University Press, 2005.

Hartnett, Stephen and Laura Stengrim, Globalization and Empire: The US Invasion of Iraq, Free Markets and the Twilight of Democracy, Tuscaloosa, AL: University of Alabama Press 2006. 
Heydemann, Steven, Networks of Privilege in the Middle East: the Politics of Economic Reform Revisited, Palgrave: Macmillan, 2004.

Heydarian, Richard Javad, How Capitalism Failed the Arab World: the economic roots and precarious future of the Middle East Uprisings, London, 2014.

Hinnebusch, Raymond, "Authoritarian Persistence, Democratization Theory and The Middle East: An Overview and Critique", Democratization, 13, no 3 (June 2006).

Hinnebusch, Raymond, "Europe and the Middle East: From Imperialism to Liberal Peace?" Review of European Studies, 4, no. 3 (July 2012).

Hinnebusch, Raymond and Ozlem Tur, Turkey-Syria Relations: between enmity and amity, Ashgate: 2013.

Huntington, Samuel P, “Democracy's Third Wave,” Journal of Democracy 2, no. 2 (Spring 1991).

Hyde-Price, A. "Normative Power Europe: a Realist Critique," Journal of European Public Policy, $13,2006,217-234$.

Jamal, Amaney, Of Empires and Citizens - Pro-American Democracy or No Democracy at All?, Princeton: Princeton University Press, 2012.

Joffe, George. "Relations between the Middle East and the West: a view from the South" In B. A. Roberson, ed. The Middle East and Europe: the Power Deficit , 45-73. London and New York: Routledge, 1994.

King, Stephan, The New Authoritarianism in the Middle East and North Africa, Bloomington, Indiana University Press, 2009

Levitsky, Steven and Lucian A. Way, "International Linkage and Democratization, "Journal of Democracy 16, no. 3, (July 2005).

Lustick, Ian, "The Absence of Middle Eastern Great Powers: "Political Backwardness in Historical Perspective," International Organization, 51, no. 4, 1997, 653-83.

Lynch, Marc, The Arab Uprising: the unfinished revolutions of the new Middle East NY: Public Affairs , 2012

Murden, Simon, Islam, the Middle East and the New Global Hegemony, Lynne Rienner Publishers, 2002

Nixon. R. “US Groups helped nurture Arab Uprising,” New York Times, 2011.

Ottoway, Marina and Thomas Carothers, "The Greater Middle East Initiative: Off to a False Start," Carnegie Endowment Policy Brief, March, 2004.

Petras, James and Henry Veltmeyer, Globalization Unmasked: imperialism in the 21st century London: Zed 2002.

Pratt, Nicola, Democracy and Authoritarianism in the Arab World, Bulder, CO: Lynne Rienner Publishers, 2007 
Robinson, William I, Promoting Polyarchy: Globalization, US Intervention, and Hegemony, New York: Cambridge University Press, 1996.

Rosecrance, Richard, Linkage Politics, New York: Free Press, 1969

Saif, Ibrahim, "Arab Leaders and Western Countries Swapping Democracy for Business Interests," Perspectives Middle East \#2: People's Power - The Arab World in Revolt, Beirut: Heinrich Boll Foundation, 2011, 106-11, http://www.boell.de/en/2011/05/06/perspectivesmiddle-east-2-peoples-power-arab-world-revolt

Salame, Ghassan, "Strong' and 'Weak" States: A Qualified Return to the Mudaddimah" in G Salame, ed. Foundations of the Arab State, London: Croom Helm, 1987.

Seelye, Kate (2011) "Syria Unrest 'Cannot Be Contained' March 28, The Daily Beast, http://www.thedailybeast.com/articles/2011/03/28/syria-unrest-cannot-be-containeddissidents-say.html

Sharabi, Hisham, Neo-Patriarchy: A Theory of Distorted Change in Arab Society, Oxford: Oxford University Press, 1996.

Shehadeh, Nael, "Economic Costs, the Arab Spring and the GCC," Gulf Research Bulletin, November 4, 2011

Solingen, Etel, Regional Orders at Century's Dawn: Global and Domestic Influence on Grand Strategy, Princeton: Princeton University Press, 1998.

Sorensen, Georg, Democracy \& Democratization, Boulder, CO: Westview Press, 1998.

Stephan, Maria J and Erica Chenoweth, "Why Civil Resistance Works: The Strategic Logic of Nonviolent Conflict, International Security, 33, no. 1, 2008, 7-44.

Takeyh, Ray, “Close but no Democracy, The National Interest, Winter, 2004/5

Tamlali, Yassin, "The 'Arab Spring': Rebirth or Final Throes of Pan-Arabism?," in, Perspectives Middle East \#2: People's Power - The Arab World in Revolt, Beirut: Heirich Boll Foundation, 2011, pp. 46-9.

Teti, Andrea, "The Globalization of Democracy and the Location of the Middle East in the Contemporary World Order." In Stephan Stetter, The Middle East and Globalization, 77-97, New York: Palgrave Macmillan, 2012.

Waltz, Kenneth, The Theory of International Politics, New York: McGraw-Hill, 1979

Zurayk, Rami (2011) Feeding the Arab Uprisings, Perspectives, Perspectives Middle East \#2: People's Power - The Arab World in Revolt, Beirut: Heirich Boll Foundation, 2011, 119-25. 